\title{
Penerapan Elastic Bands untuk Peningkatan Kekuatan Otot Lengan dan Tungkai pada Atlet Judo Asian Para Games 2018
}

\author{
The Use of Elastic Bands to Improve Arm and Leg Muscle \\ Strengthon 2018 Asian Para Games Judo Athletes
}

\author{
Muhammad Dzikry Abdullah Al Ghazaly, Nuryadi \& Yudy Hendrayana \\ Universitas Pendidikan Indonesia, Bandung, Jawa Barat, Indonesia \\ dzikryalghazaly@student.upi.edu.
}

\begin{abstract}
Abstrak
Penelitian ini dilatarbelakangi pada beberapa faktor yang ditemukan di dalam beladiri judo tunanetra yaitu proses latihan kekuatan. Seringkali para atlet tunanetra kesulitan dalam berlatih kekuatan karena hambatan yang mereka miliki dalam hal pengelihatan. Elastic bands merupakan salah satu bentuk latihan yang memudahkan proses latihan kekuatan untuk atlet judo tunanetra. Penelitian ini bertujuan untuk melihat peningkatan kekuatan otot lengan dan tungkai pada atlet judo Asian Para Games dengan menggunakan alat bantu alternative untuk latihan yaitu elastic bands. Elastic bands dianggap sebagai alat yang mampu memudahkan para atlet penyandang tunanetra untuk melakukan latihan dan meningkatkan kemampuannya dari segi kekuatan dalam melakukan olahraga judo. Subjek penelitian ini adalah 10 orang atlet judo Asian Para Games. Penelitian dilakukan dengan menggunakan metode eksperimen dimana desain penelitian yang diterapkan adalah The One-Group Pre test-Post test Design. Hasil penelitian menunjukkan bahwa terdapat peningkatan pada kekuatan otot lengan dan tungkai para atlet dimana pengujian hasil penelitian menunjukkan adanya perbedaan yang signifikan antara hasil tes awal dan hasil tes akhir. Hal ini berarti bahwa penggunaan elastic bands berhasil meningkatkan kekuatan otot lengan dan tungkai pada atlet judo Asian Para Games 2018.
\end{abstract}

Kata kunci: elastic bands, judo, kekuatan otot lengan, kekuatan otot tungkai

\begin{abstract}
The research was conducted based on some factors found regarding the process of practicing strength in blind judo. Many blind athletes had difficulty in practicing strength due to their visual impairment. Elastic bands was a form of practice that made the process of practicing strength became less difficult for blind judo athletes. The research was intended to figure out the arm and leg muscle strength improvement on Asian Para Games judo athletes by using additional equipment for practice called Elastic bands. Elastic band was an equipment designed to make the practice become less difficult for blind athletes. Furthermore, it was also expected that the equipment would increase athletes'strength in practicing judo. The subject of the research was 10 Asian Para Games athletes. The research was conducted by using experimental method in which the research design applied was The One-Group Pretest-Posttest Design. The result of the research showed the improvement through the significant difference between the pre test and post test result. The result described that the use of Elastic Bands succeed to improve arm and leg muscle strength of 2018 Asian Para Games judo athletes.
\end{abstract}

Keywords: elastic bands, judo, arm muscle strength, leg muscle strength 


\section{PENDAHULUAN}

Judo adalah olahraga tradisional yang berasal dari jepang. Judo ditemukan oleh Profesor Jigoro Kano pada tahun 1882 sebagai awal dari keinginannya dalam moderenisasi olahraga jujutsu. Sebagai olahraga beladiri, judo dipandang sebagai beladiri yang keras dengan teknik-teknik bantingannya. Penggunaan teknik-teknik dalam judo tentunya melibatkan kekuatan dari otot-otot yang dimiliki oleh seorang atlet (Sukadiyanto, 2005) terutama kekuatan lengan, karena fungsinya untuk menarik dan mendorong, menghilangkan keseimbangan lawan (kuzushi), juga memindahkan atau menarik sebagian atau seluruh tubuh dari satu tempat ketempat lain (Dewi, 2013). Lebih lanjut menurut Juhanis (2012) Peranan kekuatan otot lengan dalam melakukan bantingan sangatlah penting karena di samping dapat menunjang dalam memperoleh nilai bantingan pinggang. Dengan demikian latihan yang biasa dikembangkan untuk dapat melatih kekuatan ialah dengan mengontraksikan otot-otot tersebut. Harsono (1998) mendefinisikan kekuatan itu sendiri sebagai kemampuan otot untuk membangkitkan tegangan terhadap suatu tahanan.

Penggunaan elastic bands sebagai sarana alternative dalam melatih kekuatan sudah mulai banyak digunakan oleh beberapa cabang olahraga. Elastic bands adalah sebuah alat bantu yang terbuat dari karet elastis yang dapat memberikan beban tambahan melalui regangannya dan mudah digunakan dibandingkan dengan mesin (Mikesky et al. 1994; Colado \& Triplett, 2008). Elastisitas yang dimiliki oleh elastic bands bias digunakan sebagai beban di dalam sebuah gerakan yang dilakukan. Beban yang diberikan pun bervariasi tergantung dari jenis atau ketebalan karet yang digunakan. Alat ini mudah untuk dibawa kemana pun dan mudah untuk digunakan karena tidak memiliki konstruksi yang rumit. Selain itu, elastic bands juga lebih aman untuk digunakan karena alat ini lentur dan tidak akan mengakibatkan cedera jika bersentuhan dengan kulit manusia. Dari kajian Mikesky dkk (1994) menunjukkan bahwa latihan dengan menggunakan elastic bands telah berfungsi secara praktis dan efektif.

Beberapa penelitian yang telah dilakukan adalah pemberian latihan fisik kepada wanita paruh baya dengan menggunakan elastic bands. Penelitian ini telah menunjukan bahwa penggunaan elastic bands memberikan peningkatan signifikan pada tingkat fungsi kognitif, fungsi fisik, dan kekuatan otot (Yoon et al., 2017). Penelitian dari Yasuda dkk (2014) menunjukkan bahwa latihan dengan menggunakan elastic bands telah meningkatkan aktivasi otot dan menjadi metode efektif untuk membangun hipertrofi otot pada orang dewasa yang memiliki aktivitas rendah.

Dengan karakteristik elastic bands yang telah dijelaskan, alat ini cocok untuk digunakan sebagai sarana alternative latihan kekuatan bagi masyarakat umum, atlet, para penyandang disabilitas (Dhar \& Agarwal, 2015), para lansia (Nyberg, 2014), anakanak (Özsu, 2018; Sahin dkk, 2016) orang yang sedang penyembuhan otot sekalipun (Skalsdkk, 2018) dan bahkan baru-baru ini telah dimodifikasi dan diterapkan pada fungsi yang lebih besar. Penggunaan alat bantu alternative dapat membuat proses 
berlatih atlet-atlet berkebutuhan khusus lebih mudah dan tentunya menjadi lebih aman dan ramah. Selain itu, alat yang digunakan juga tetap mampu memberikan hasil latihan yang optimal bagi komponen-komponen latihan yang dituju contohnya dalam latihan kekuatan. Diharapkan atlet dengan hambatan pengelihatan tidak perlu khawatir lagi ketika berlatih beban karena bentuk latihan kekuatan alternatif yang telah diberikan. Kekhawatiran yang biasanya muncul saat memasuki ruang beban bisa diminimalisir dengan penggunaan alat bantuk arena penggunaan alat ini tidak menuntut banyak perpindahan posisi sebagaimana di tempat gym. Berdasarkan hal-hal tersebut, penelitian ini ditujukan untuk melihat pengaruh dari penerapan elastic bands terhadap kekuatan pada atlet judo tunanetra.

\section{METODE PENELITIAN}

Penelitian inimerupakan penelitian kuantitatif dengan menggunakan metode eksperimen. Metode kuantitatif dapat diartikan sebagai metode penelitian yang berdasar pada filsafat positifmen, digunakan untuk meneliti sampel pada populasi atau sampel tertentu, teknik pengambilan sampel umumnya dilakukan secara random, pengumpulan data menggunakan instrument penelitian, analisis data yang bersifat kuantitatif/statistik (Sugiyono, 2006). Sedangkan metode penelitian eksperimen merupakan penelitian yang dimaksudkan untuk mengetahui adanya akibat atau tidak terhadap subjek yang dikenai perlakuan (Arikunto, 2002).

Desain penelitian yang digunakan dalam penelitian ini adalah The One-Group Pre testPost test Design. Dalam desain ini penelitian ini menggunakan tipe rancangan pemasangan subjek melalui tes awal dan tes akhir. Subjek penelitian diambil dari sejumlah atlet pelatnas Asian Para Games 2018 yang 10 orang diantaranya dijadikan sebagai sampel penelitian. Data penelitian terkumpul dengan menggunakan dua instrument penelitianya itu alat leg dynamometer, alat hand dynamo meter. Semua data yang diambil kemudian dianalisis dengan menggunakan teknik pengolahan data untuk mencari rata-rata, simpangan baku/standar deviasi dan varians. Langkah-langkah perhitungan menggunakan software SPSS statistic 22. Perhitungan yang dilakukan yang diantaranya adalah uji normalitas data, uji homogenitas data, dan uji t paired sampel test.

\section{HASIL DAN PEMBAHASAN}

\subsection{Hasil penelitian}

\section{Deskripsi hasil data penelitian}

Pre test dilakukan dengan tujuan untuk mengetahui dan mengukur kekuatan otot lengan dan kekuatan otot tungkai awal atlet pelatnas judo Asian Para Games 2018. Dalam penelitian ini, peneliti memberikan perlakuan kepada sampel berupa program latihan elastic bands dengan jumlah sample yang telah ditentukan sebelumnya. Penelitian ini dilaksanakan pada bulan Agustus sampai bulan September. Tempat yang digunakan dalam penelitian ini berada di Dojo judo Manahan Surakarta (solo). Data pre test digunakan untuk mendapatkan kemampuan dasar dalam penelitian. Sedangkan Post test dilakukan dengan tujuan mengukur dan mengetahui kemampuan atlet setelah diberikan perlakuan (treatment) dengan latihan 
elastic bands. Berikut di bawah ini nilai dari pre test dan post test yang dilakukan di akhir pertemuan pada masing-masing atlet.

\section{Pengujian Hasil Penelitian}

Data yang telah diperoleh melalui pre test dan post test kemudian dihitung dan dianalisis untuk menentukan langkah selanjutnya dalam melakukan penelitian. Perhitungan dan analisis yang dilakukan meliputi uji normalitas, uji homogenitas, dan uji hipotesis. Hasil perhitungan dan análisis terhadap data hasil penelitian akan terdapat tiga pengujian hipotesis (uji-t) yaitu:

1) Uji perbedaan hasil pre test dan post test tes lengan

2) Uji perbedaan hasil pre test dan post test tes tungkai

\section{Uji t Lengan (Pull)}

Berdasarkan hasil uji normalitas dan homogenitas diperoleh bahwa uji Paired Sample t-Test dapat dilakukan. Adapun rumusan hipotesis dari uji kali ini adalah:

H0: Tidak terdapat perbedaan rata-rata skor Pre test dan Post test kekuatan lengan yang signifikan dari penerapan elastic band H1: Terdapat perbedaan rata-rata skor Pre test dan Post test kekuatan lengan yang signifikan dari penerapan elastic band

Kriteria uji yang digunakan adalah jika nilai sig. $<\alpha(\alpha=0.05)$ maka tolak $\mathrm{H} 0$ dan jika selain dari itu maka terima H0. Berikut ini merupakan data uji Paired Sample t-Test dengan menggunakan perangkat lunak SPSS pada tabel 1 .

Tabel 1. Uji t, Pre test dan Post test Lengan (Pull)

Paired samples Test

\begin{tabular}{|c|c|c|c|c|c|c|c|c|}
\hline & \multicolumn{5}{|c|}{ Paired Differences } & \multirow{3}{*}{$\mathrm{t}$} & \multirow{3}{*}{ df } & \multirow{3}{*}{$\begin{array}{c}\text { Sig. } \\
\text { (2-Tailed) }\end{array}$} \\
\hline & \multirow[t]{2}{*}{ Mean } & \multirow[t]{2}{*}{$\begin{array}{c}\text { Std. } \\
\text { Deviation }\end{array}$} & \multirow{2}{*}{$\begin{array}{l}\text { Std. } \\
\text { Error } \\
\text { Mean }\end{array}$} & \multicolumn{2}{|c|}{$\begin{array}{c}\text { 95\% Confidence } \\
\text { Interval of the } \\
\text { Difference }\end{array}$} & & & \\
\hline & & & & Lower & Upper & & & \\
\hline $\begin{array}{ll}\text { Pair } & \text { Post Test - } \\
1 & \text { Pre Test }\end{array}$ & 3.25000 & 2.86986 & .90753 & 1.19702 & 5.30298 & 3.581 & 9 & .006 \\
\hline
\end{tabular}

Diperoleh bahwa nilai signifikansi lebih kecil dari 0.05 sehingga $\mathrm{H} 0$ ditolak, artinya terdapat perbedaan rata-rata skor pre test dan post test kekuatan tarikan lengan yang signifikan dari penerapan elastic band.

\section{Uji t Lengan (Push)}

Berdasarkan hasil uji normalitas dan homogenitas diperoleh bahwa uji Paired Sample t-Test dapat dilakukan. Adapun rumusan hipotesis dari uji kali ini adalah: H0: Tidak terdapat perbedaan rata-rata skor pre test dan post test kekuatan lengan yang signifikan dari penerapan elastic band

H1: Terdapat perbedaan rata-rata skor pre test dan post test kekuatan lengan yang signifikan dari penerapan elastic band

Kriteria uji yang digunakan adalah jika nilai sig. $<\alpha(\alpha=0.05)$ maka tolak $\mathrm{H} 0$ dan jika selain dari itu maka terima $\mathrm{H} 0$. Berikut ini merupakan data uji Paired Sample t-Test dengan menggunakan perangkat lunak SPSS pada tabel 2. 
Tabel 2. Uji t, Pretest dan Postest Lengan (Push)

\begin{tabular}{|c|c|c|c|c|c|c|c|c|}
\hline \multicolumn{9}{|c|}{ Paired samples Test } \\
\hline & \multicolumn{5}{|c|}{ Paired Differences } & \multirow{3}{*}{$\mathrm{t}$} & \multirow{3}{*}{$d f$} & \multirow{3}{*}{$\begin{array}{c}\text { Sig. } \\
\text { (2-Tailed) }\end{array}$} \\
\hline & \multirow[t]{2}{*}{ Mean } & \multirow[t]{2}{*}{$\begin{array}{c}\text { Std. } \\
\text { Deviation }\end{array}$} & \multirow[t]{2}{*}{$\begin{array}{l}\text { Std. Error } \\
\text { Mean }\end{array}$} & \multicolumn{2}{|c|}{$\begin{array}{l}\text { 95\% Confidence } \\
\text { Interval of the } \\
\text { Difference }\end{array}$} & & & \\
\hline & & & & Lower & Upper & & & \\
\hline $\begin{array}{ll}\text { Pair } & \text { Post Test - } \\
1 & \text { Pre Test }\end{array}$ & 4.50000 & 3.39116 & 1.07238 & 2.07411 & 6.92589 & 4.196 & 9 & .002 \\
\hline
\end{tabular}

Pada tabel 2 diperoleh bahwa nilai signifikansi lebih kecil dari 0.05 sehingga $\mathrm{H} 0$ ditolak, artinya terdapat perbedaan rata-rata skor pre test dan post test kekuatan dorongan lengan yang signifikan dari penerapan elastic band.

\section{Uji t Tungkai}

Berdasarkan hasil uji normalitas dan homogenitas diperoleh bahwa uji Paired Sample t-Test dapat dilakukan. Adapun rumusan hipotesis dari uji kali ini adalah:

H0: Tidak terdapat perbedaan rata-rata skor pre test dan post test kekuatan otot tungkai yang signifikan dari penerapan elastic band

H1: Terdapat perbedaan rata-rata skor pre test dan post test kekuatan otot tungkai yang signifikan dari penerapan elastic band

Kriteria uji yang digunakan adalah jika nilai sig. $<\alpha(\alpha=0.05)$ maka tolak $\mathrm{H} 0$ dan jika selain dari itu maka terima H0. Berikut ini merupakan data uji Paired Sample t-Test dengan menggunakan perangkat lunak SPSS pada tabel 3 .

Tabel 3. Uji t, Pretest dan Postest Tungkai

\begin{tabular}{llrr}
\hline & t & df & \multicolumn{2}{c}{ Sig. (2-tailed) } \\
\hline Pair 1 Post Test - Pre Test & 10.062 & 9 & .000 \\
\hline
\end{tabular}

Pada tabel 3 diperoleh bahwa nilai signifikansi lebih kecil dari 0.05 sehingga $\mathrm{H} 0$ ditolak, artinya terdapat perbedaan ratarata skor pre test dan post test kekuatan otot tungkai yang signifikan dari penerapan elastic bands.

\subsection{Pembahasan Penelitian}

Pada penelitian sebelumnya ditemukan bahwa aktivasi otot terbukti meningkat selama latihan beban rendah dengan BFR (Takarada, 2000). Sebagai upaya tindak lanjut kami ingin mengetahui peningkatan aktivasi otot dengan menggunakan karet gelang. Berdasarkan hasil pengolahan data dan analisis yang dilakukan dari proses penelitian hingga perhitungan dan pengujian hipotesis yang telah dituliskan diperoleh berbagai temuantemuan yang ada. Hasil pengolahan data menunjukkaan bahwa metode latihan elastic bands memberikan pengaruh yang signifikan terhadap peningkatan kekuatan lengan, kekuatan tungkai dan juga penguasaan teknik bantingan atlet pelatnas judo Asian Para Games 2018. Hal ini sesuai dengan pendapat dari Yasuda dkk (2014) yang mengatakan bahwa "resistance-training program for older adults using elastic bands improves 
muscle strength".

Peningkatan kekuatan lengan terlihat dari tes pull dan tes push pada alat hand dynamo meter yang dilakukan. Jumlah peningkatan hasil tes didapat dari perbandingan yang dilakukan antara tes awal dan tes akhir para atlet. Data pertama mengenai tes pull pada Tabel 4.5 menunjukkan bahwa nilai $\mathrm{t}$ hitung yang diperoleh dari rata-rata antara nilai pretest dan posttest lengan (pull) adalah $3.581>\mathrm{t}$ tabel pada taraf signifikansi $95 \%$ dan derajat bebas $d k=n-2=8$ yaitu sebesar 2.306. Ini menunjukkan bahwa nilai pretest dan posttest kekuatan lengan pada tes pull memiliki perbedaan secara signifikan atau dengan kata lain metode latihan elastic bands dapat memberikan peningkatan hasil yang signifikan.

Data kedua pada Tabel 4.8 menunjukkan bahwa nilai $\mathrm{t}$ hitung yang diperoleh dari rata-rata antara nilai pre test dan post test lengan (push) adalah $4.196>\mathrm{t}$ tabel pada taraf signifikansi $95 \%$ dan derajat bebas $d k=n-2=8$ yaitu sebesar 2.306. Ini menunjukkan bahwa nilai pre test dan post test kekuatan lengan pada tes push memiliki perbedaan secara signifikan atau dengan kata lain metode latihan elastic bands dapat memberikan peningkatan hasil yang signifikan. Hal tersebut dapat dilihat dari rata-rata nilai pre test dan post test atlet yang mengalami peningkatan cukup berarti sebesar 4,500.

Data ketiga Dapat dilihat pada Tabel 4.11 menunjukkan bahwa nilai $\mathrm{t}$ hitung yang diperoleh dari rata-rata antara nilai pretest dan postest tungkai adalah $10.062>\mathrm{t}$ tabel pada taraf signifikansi $95 \%$ dan derajat bebas $d k=n-2=8$ yaitu sebesar 2.306 .
Ini menunjukkan bahwa nilai pre test dan post test tungkai berbeda secara signifikan atau dengan kata lain metode latihan elastic bands dapat memberikan peningkatan hasil yang signifikan. Hal tersebut dapat dilihat dari rata-rata nilai pre test dan post test atlet yang mengalami peningkatan cukup berarti sebesar 3,0000.

Namun di dalam pelaksanaan penelitian ini, penulis juga menemukan kendala dalam pemakaian elastic bands sebagai metode latihan kekuatan. Dalam metode ini, peningkatan beban yang bisa dilakukan sangat terbatas. Jika jumlah repetisi sudah melampaui atau tidak sesuai dengan tujuan latihan (dalam kasus ini hypertrophy), maka pelatih akan kesulitan dalam meningkatkan beban latihan. Hal yang bisa dilakukan untuk menyiasati ini adalah dengan memendekkan karet elastic bands yang dipakai agar regangan menguat atau mengganti dengan elastic bands lain dengan resistensi yang lebih besar.

Berdasarkan uraian di atas dapat disimpulkan bahwa melaluipenerapan metode latihan elastic band dalam pelatihan judo dapat memberikan pengaruh yang signifikan terhadap kekuatan lengan dan kekuatan tungkai atlet pelatnas tunanetra Asian Paragames 2018. Di samping itu, metode ini juga memberikan pengaruh yang signifikan terhadap keterampilan judo. Berikutnya peningkatan pada tes keterampilan yaitu dengan nilai rata-rata yang diperoleh atlet dalam memperagakan teknik ippon seoi nage pada saat pre tes sebesar 7,10, kemudian nilai rata-rata yang diperoleh atlet pada saat post test sebesar 8,50. Kedua, nilai rata-rata yang diperoleh atlet dalam memperagakan teknik 
o goshi pada saat pre test sebesar 7,30, dan nilai rata-rata yang diperoleh atlet pada saat post-tes sebesar 8,50. Ketiga, nilai rata-rata yang diperoleh atlet dalam memperagakan teknik osoto gari pada saat pre test sebesar 7,30 , kemudian nilai rata-rata yang diperoleh pada saat post test sebesar 8,60. Berdasarkan analisis hasil penelitian dan pembahasan dapat disimpulkan bahwa melalui penerapan metode latihan elastic bands dalam pelatihan judo dapat meningkatkan kekuatan lengan, kekuatan tungkai, dan keterampilan judo pada atlet tunanetra Asian Para Games 2018.

\section{SIMPULAN}

Berdasarkan hasil penelitian dan perhitungan serta analisis data yang telah dilakukan, maka dapat ditarik kesimpulan bahwa: Penerapan elastic bands memberikan dampak secara signifikan terhadap kekuatan lengan dan kekuatan tungkai pada atlet judo Asian Para Games 2018.

\section{DAFTAR RUJUKAN}

Arikunto, S. (2002). Prosedur Prosedur Penelitian: Suatu Pendekatan Praktek. Edisi Revisi VII. Jakarta: Rieneka Cipta.

Colado, J. C \& Triplett, N. T. (2008). Effects of a short-term resistance program using elastic bands vs. weight machines for sedentary middle-aged women. J Strength Cond Res, 22, 1441-1448.

Dewi, K. N. (2013). Survey Kekuatan Menarik dan Mendorong Otot Lengan Atlet Judo Putra UPT Smanor. Fakultas Ilmu Keolahragaan. Universitas Negeri Surabaya.

Dhar, S \& Agarwal, S. (2015). Effectiveness of an Elastic Band Exercise Protocol in Tri-Compartmental Osteoarthritis of the Knee. Indian Journal of Physiotherapy and Occupational Therapy, 9 (2), 176-181.

Harsono.1988. Coaching dan Aspek-Aspek Psikologis dalam Coaching.New York: Albany.

Juhanis. (2012). Hubungan Kekuatan Otot Tungkai Dan Kekuatan Otot Lengan dengan Kemampuan Bantingan Pinggang pada Olahraga Gulat Mahasiswa FIK UNM Makassar. Jurnal ILARA, 3 (1), 60 - 69.

Mikesky, A., Topp, R., Wigglesworth, J., Harsha, D. M \& Edwards, J. (1994). Efficacy of a home based training program for older adults using elastic tubing. European Journal Appl Physiol Occup Physiol, 69, 316320 .

Nyberg, A., Hedlund, M., Kolberg, A., Alm, L., Lindström, B., \& Wadell, K. (2014). The accuracy of using elastic resistance bands to evaluate muscular strength. European Journal of Physiotherapy, 16(2), 104-112.

Ozsu, I. (2018). Effects of 6-Week Resistance Elastic Band Exercise on Functional Performances of 8-9 Year-Old Children.Journal of Education and Training Studies, 6, (12a), 23-28.

Şahin, G., Aslan, M., \& Demir, E. (2016). Short-term effect of back squat with an elastic band on the squat and vertical jump performance in trained children. Journal of Physical Education and Sport, 16(1), 97.

Skals, S., Vinstrup, J., Sundstrup, E., Jakobsen, M. D., Andersen, C. H., \& Andersen, L. L. (2018). Shoulder and arm muscle activity during elastic band exercises performed in a hospital bed Sebastian. The Physician and Sportsmedicine, 46(2), 233-241.

suda, T., Fukumura, K., Tomaru, T., \& Nakajima, T. (2016). Thigh muscle size and vascular function after blood flow-restricted elastic band training in older women.Oncotarget, 7(23), 33595-33607.

Sugiyono. (2006). Metode Penelitian kuantitatif, kualitatif dan R \& D. Bandung : Alfabeta.

Sukadiyanto. (2005). Pengantar Teori dan Metodologi Melatih Fisik. Yogyakarta: FIK Universitas Negeri Yogyakarta.

Takarada Y, Nakamura Y, Aruga S, Onda T, Miyazaki S, Ishii N. (2000). Rapid increase in plasma growth hormone after low-intensity resistance exercise with vascular occlusion. Journal Appl Physiol, 88, 61-65.

Yasuda, T., Yamaosba, T \&Masamune, K. (2014). Effects of Low-Load, Elastic Band Resistance Training 
Combined With Blood Flow Restriction on Muscle Size and Arterial Stiffness in Older Adults. Journals of Gerontology: Biological Sciences, 1-10.

Yasuda., Fukumara, K., Fukuda, T.,Lida, H., Imuta, H., Sato, Y., Yamasoba\&Nakajima, T. (2014). Effects of lowintensity, elastic band resistance exercise combined with blood flow restriction on muscle activation $\mathrm{T}$. Scandinavian Journal Medicine Science Sports, 24, 55-61

Yoon, D. H., Kang, D., Kim, H., Kim, J.-S., Song, H. S., \& Song, W. (2017). Effect of elastic band-based highspeed power training on cognitive function, physical performance and muscle strength in older women with mild cognitive impairment. Geriatrics \& Gerontology International, 17(5), 765-772. 